\title{
The Effect of Small Doses of Kainic Acid on the Area CA3 of the Hippocampal Formation. An Electron Microscopic Study*
}

\author{
Hiroko L. Obata, Seiichi Kubo, Haruo Kinoshita, Yoshinori Murabe and \\ Yasuhiko IBATA \\ Department of Anatomy (Prof. Y. IвatA), Kyoto Prefectural University of Medicine, Kyoto, Japan
}

Received July 23, 1980

Summary.. The toxic effect on area CA3 of the hippocampus of the rat of small doses of kainic acid (KA) injected into the lateral ventericles was examined by electron microscopy. The most characteristic feature revealed was degeneration in the pyramidal cell somata and in their dendrites from as early as $3 \mathrm{hr}$ after injection. We found four types of degenerating pyramidal cells probably corresponding to their susceptibility to KA intoxication. We also detected degenerating preterminal axons and terminals in addition to degenerating pyramidal cells and dendrites. Temporary structural alterations of the mossy fiber endings and intimate adhesional contacts between the mossy fiber endings were also observed. The response of the glia to the damage area CA3 was an increase in the number of astroglia and macrophages in the early stage followed later by mobilization of microglia and astroglia for the formation of scar tissue.

Kainic acid (KA), a glutamate analogue, is considered to be neurotoxic and neuroexcitant to several kinds of neurons in the CNS (see McGeER et al., 1978). Its effects on neurons have been examined in vivo in the neostriatum (HATTORI and McGeER, 1977; Wuerthele et al., 1978), the hippocampus (NAdler et al., 1978; Olney et al., 1979) and the cerebellum (HeRndon and CoYLe, 1978) as well as in the arcuate nucleus (Olney et al., 1974; Mizukawa et al., 1976), and in vitro in some areas of the CNS (SEIL et al., 1978, 1979). It is also regarded as a useful tool for the destruction of a particular neuron system, such as the hippocampal formation, by the application of a small quantity into a restricted area or into the ventricle (NADLER et al., 1978). In those investigations, it has been supposed that neuronal cell somata and their dendrites are primarily damaged, while axons passing through or terminating are spared from degeneration (NADlER et al., 1978; Coyle, 1978). Although the mechanism of KA neurotoxicity has not yet been clarified, its effect may be closely correlated with the receptors of glutamate on neuronal perikarya or dendrites (OlNEY et al., 1974; COYLE, 1978). However there are relatively few papers revealing by electron microscopy alterations due to KA neurotoxicity, particularly when small doses are injected. In the present study, therefore, we have attempted to scrutinize by electron micro-

* This work was supported in part by a grant (No. 321426) from the Ministry of Education, Science and Culture, Japan. 
scopy and at varying times after dosage the restricted areas of the hippocampus (CA3) which are destroyed by small amounts of $\mathrm{KA}$ administered into the lateral ventricles, with special reference to the alteration of the neuronal perikarya, their processes, afferent fibers and other surrounding structures such as glial components.

\section{MATERIALS AND METHODS}

Eighty adult male Wistar albino rats each weighing about $250 \mathrm{~g}$ were used in the present study. Under sodium pentobarbiturate anesthesia a hole was drilled in the skull of each animal at a point $2 \mathrm{~mm}$ lateral to the midline and $1 \mathrm{~mm}$ anterior to the bregma. A $1 \mu \mathrm{l}$ Hamilton syringe containing $0.3 \mu \mathrm{g}$ (1.5 nmole) KA (Sigma Chem. Co. Ltd) dissolved in $0.3 \mu \mathrm{l}$ saline was inserted to a depth of $4 \mathrm{~mm}$ from the surface of the skull and KA was injected into the lateral ventricle over a $15 \mathrm{~min}$ period. NADLER et al. (1978) stated that an increasing dose of KA will destroy the pyramidal cells in a widespread area of the hippocampus. We therefore first determined the minimum dose of $\mathrm{KA}$ required to destroy a restricted area and found that $0.3 \mu \mathrm{g}$ KA destroyed nearly all of the pyramidal cell layer in the area CA3. This dose schedule was adapted for use throughout our investigation.

Rats were sacrificed at 1, 3, 8, 24, $72 \mathrm{hr}, 1$ and 3 weeks after injection. For light microscopic observations they were decapitated, the brains being removed and fixed with $10 \%$ neutralized formalin. For electron microscopy they were sacrificed by transcardial perfusion with Palay's fixative (1\% paraformaldehyde, $1 \%$ glutaraldehyde) over a $5 \mathrm{~min}$ period, the brains were removed and the hippocampal formation divided into two groups, dorsal and ventral. Blocks $1 \mathrm{~mm}$ thick were cut from the tissues in which the specific cellular arrangement of the hippocampal formation was recognized. Thereafter they were immersed in Palay's fixative for $2 \mathrm{hr}$. After washing with Palay's buffer, they were postfixed in $2 \%$ osmium tetroxide solution for $2 \mathrm{hr}$ at $4^{\circ} \mathrm{C}$, followed by dehydration in a graded series of acetone and embedded in Epon 812 mixture. Semithin sections $2 \mu \mathrm{m}$ thick were stained with $1 \%$ toluidine blue and checked for degeneration of the pyramidal cell layer in area CA3 by light microscopy. In paraffin sections stained with hematoxylin-eosin and in frozen sections treated by FinK-HeIMER's procedure I (HEIMER, 1970) for degenerating neurons, we confirmed that restricted degeneration had occurred in the same region. Ultrathin sections were cut and stained with uranyl acetate and lead acetate and examined with a JEM 100B electron microscope. As controls we injected $0.3 \mu$ l saline into the lateral ventricle of three animals which were examined in the same manner as the experimental animals. No morphological alteration could be detected in any regions of the hippocampal formation in the control animals.

\section{RESULTS}

The animals given KA showed convulsive symptoms similar to those described by NADLER et al. (1978), namely tremor of the vibrassae, light seizure of fore-limbs and occasionally bulging of the eye ipsilateral to the injection. These symptoms lasted for about $4 \mathrm{hr}$. 


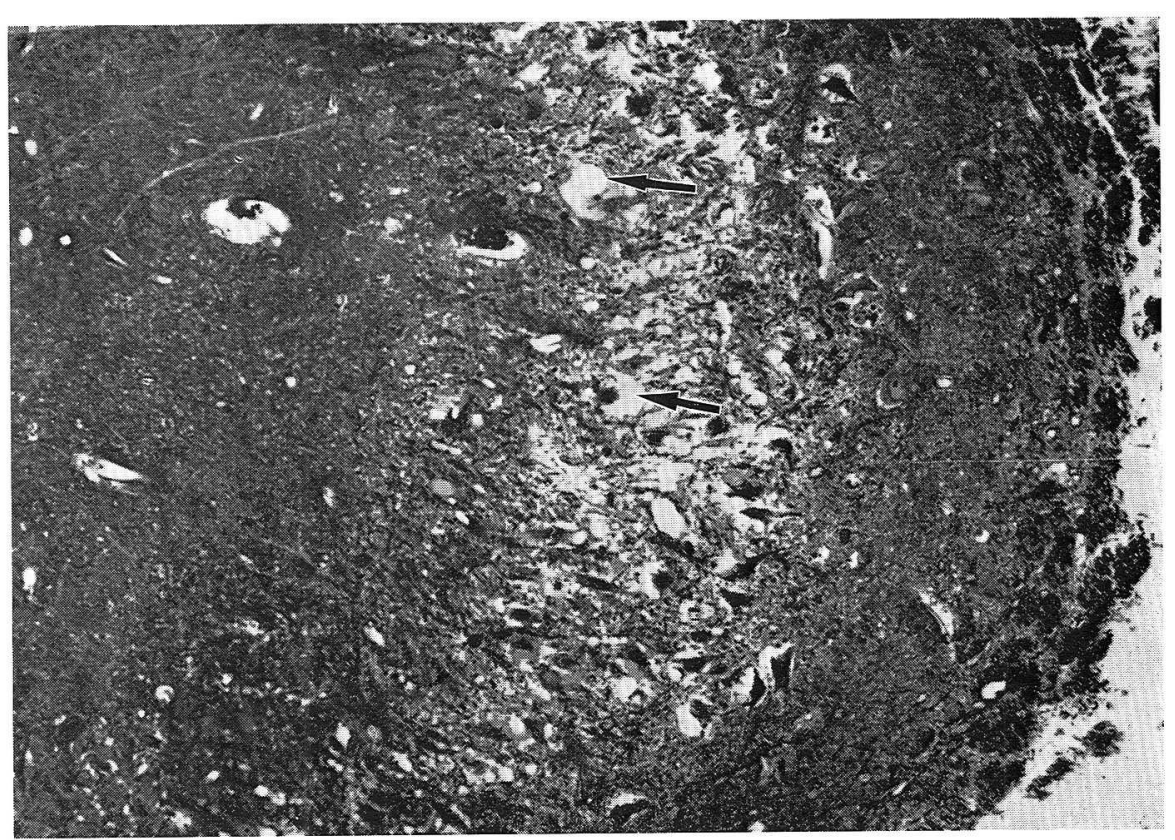

Fig. 1. Toluidine blue stained semi-thin section showing damage in area CA3 of the hippocampal formation at $24 \mathrm{hr}$ after injection. The damaged area is recognised by the empty or weakly stained tissue and degenerating neurons (arrows). $\quad \times 260$

\section{Degeneration of the perikarya and dendrites of the pyramidal cells}

Degenerating pyramidal cells were already recognizable as vacuolated masses in area CA3 of the dorsal hippocampus $1 \mathrm{hr}$ after injection, but they were not prominent. At $3 \mathrm{hr}$ after injection they had increased in number and many vacuolated pyramidal cells were observed by light microscopy in semithin sections (Fig. 1). At this stage the stratum radiatum of area $\mathrm{CA} 3$, which mainly consists of apical dendrites, was difficult to stain with toluidine blue. The damaged area was considered to be the stratum pyramidale and stratum radiatum of area CA3.

Electron microscopy indicated that degeneration was confied to the neuronal perikarya and dendrites, particularly the apical ones, of the pyramidal cells in this survival period. Four types of degenerating pyramidal neurons were observed during this experiment. The population of each neuron type was correlated to the survival period. The most frequently encountered degenerating neurons in the early stages, e.g. at $3 \mathrm{hr}$, were those which showed an almost vacant profile with scanty cytoplasm. Their nuclei, with a sparse distribution of chromatin, except for an accumulation of RNA particles in the vicinity of nuclear membrane, seemed to float in deteriorated cytoplasm (Fig. 2a). Another type of degenerating neuron, containing many large vacuoles which are thought to be expanded rough-surfaced endoplasmic reticulum (rER) and Golgi complex, together with less dense matrices and a few mitochondria, were also observed at an early stage (Fig. 2b). The nuclei of these cells also showed sparse distribution of chromatin.

In a more advanced stage, $8 \mathrm{hr}$ after the injection, degenerating neurons of a 

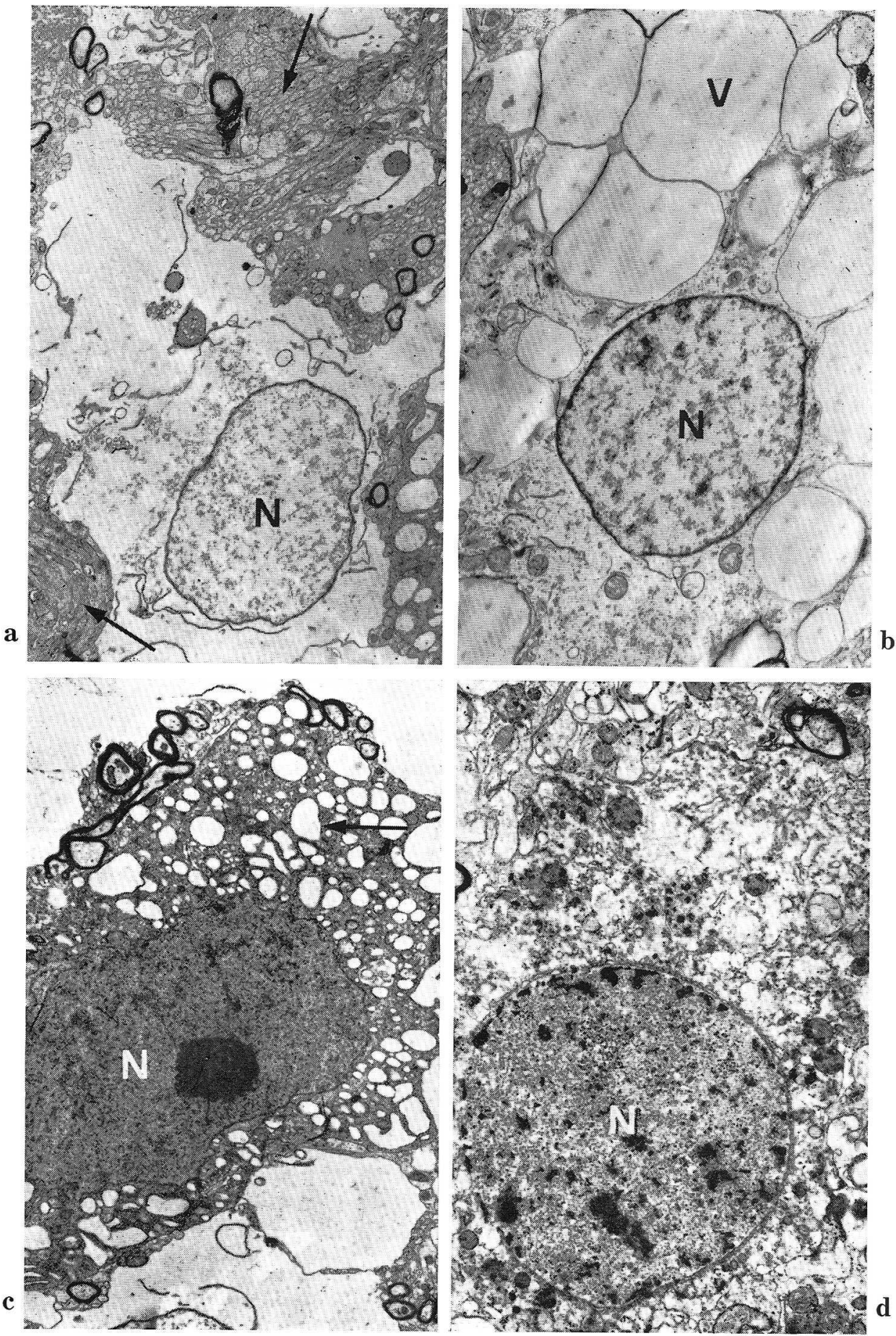

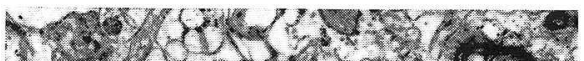

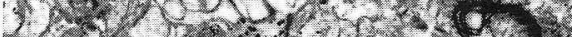

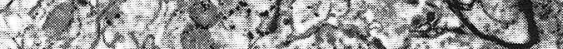

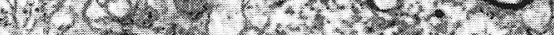

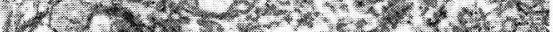

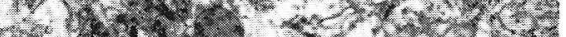

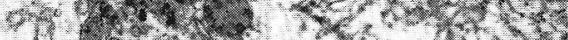

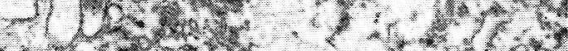

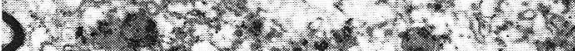

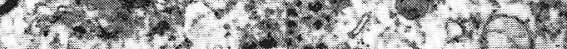

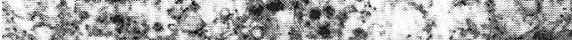

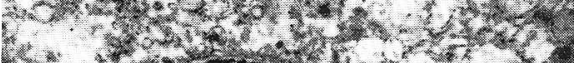

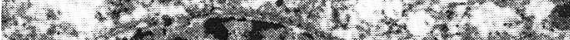

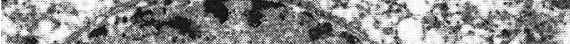

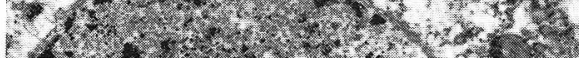

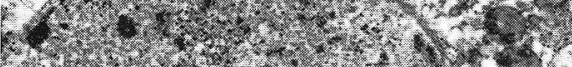

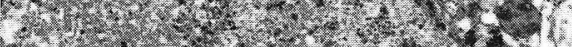

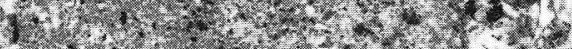

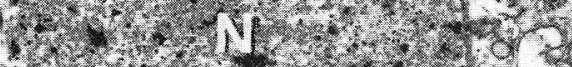

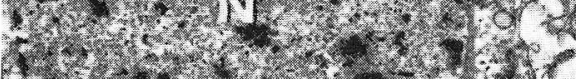

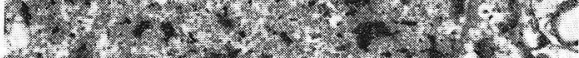

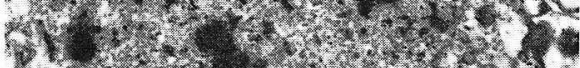

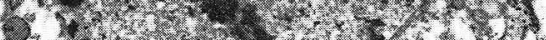

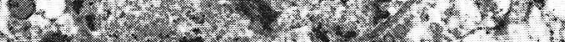

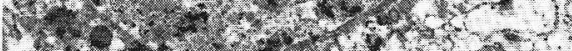

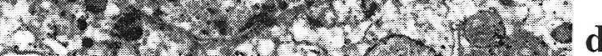

Fig. 2. Legend on the opposite page. 
third type with shrunken configuration and high electron density were observed, although a few of these were also found earlier. They contained swollen rER, dark mitochondria and many polysomes (Fig. 2c). The fourth type of degenerating neurons also appeared as cells with a shrunken configuration. However their cell organelles such as rER seemed to be disrupted, their fragments being diffusely distributed throughout the cytoplasm (Fig. 2d).

Twenty-four $\mathrm{hr}$ after injection degenerating pyramidal neurons as a whole became more numerous than at any other time. The third and fourth types particularly increased in number. On the other hand, the first and second types of degenerating neurons, frequently encountered in earlier stages, were less abundant and in their place numerous large empty spaces were observed.

Degenerating pyramidal neurons of the third and fourth types were still present $72 \mathrm{hr}$ after injection, but we could no longer detect the first and second types. The debris of cell organelles were scattered in the damaged area CA3. The residual elements of area CA3 comprised a relatively small number of surviving pyramidal neurons and their processes, degenerating dendrites, afferent neuronal fibers including terminals, and glial elements. They seemed to float in the vacant space of the damaged area. Debris of degenerating perikarya of the pyramidal cells could not be found 1 week after injection but small number of surviving pyramidal neurons, their processes and glial elements, were observed in the disorganized pyramidal cell layer. At 3 weeks after injection, the morphological features were similar to those at 1 week and the vacant spaces were filled with other components such as glial processes.

Degeneration of the dendrites of pyramidal cells was first noted $3 \mathrm{hr}$ after injection. Two types of degenerating dendrites were seen; one being dark and shrunken (Fig. 3a), the other clear swollen and containing small vacuoles (Fig. 3b). Degeneration was observed in both apical and basal dendrites, the proximal portion of the former being particularly affected. Some dendrites were identified as postsynaptic elements with synaptic membrane specialization. However, they were still scanty at this early stage. They increased markedly in number $8 \mathrm{hr}$ after injection. Some of them contained large vacuoles and others, many myeline figures.

Twenty-four hr after injection, degeneration of the dendrites reached a peak and there was an abundance of degenerating dendrites in the damaged area CA3. We were able to follow them until the $72 \mathrm{hr}$ stage but at that time most of them had become shrunken and electron dense, and it was diffuclt to find degenerating dendrites containing numerous vacuoles. Thereafter they gradually decreased in

Fig. 2. a-d. Electron micrographs showing four types of degenerating pyramidal cells in area CA3 of the hippocampal formation. $N$ nucleus. a. Swollen degenerating pyramidal cell showing an almost vacant configuration with sparse cell organelles at $3 \mathrm{hr}$ after injection. There is also poor development of nuclear chromatin. Bundles of mossy fibers (arrow) are present around this neuron. $\times 4,300$. b. Swollen degenerating pyramidal cell containing numerous large empty vacuoles at $3 \mathrm{hr}$ after injection. Nuclear chromatin and cell organelles including mitochondria are poorly developed in this neuron. $V$ vacuole. $\times 6,500$. c. Dark degenerating pyramidal cell characterized by dense nuclear and cytoplasmic matrices and expanded rough surfaced ER (arrow) at $8 \mathrm{hr}$ after injection. A damaged area without cytoplasmic components surrounds this neuron. $\times 4,300$. d. Degenerating pyramidal cell showing cytoplasmic deterioration and cell organelle degeneration at $8 \mathrm{hr}$ after injection. The nucleus of this neuron is pyknotic. $\times 8,700$ 

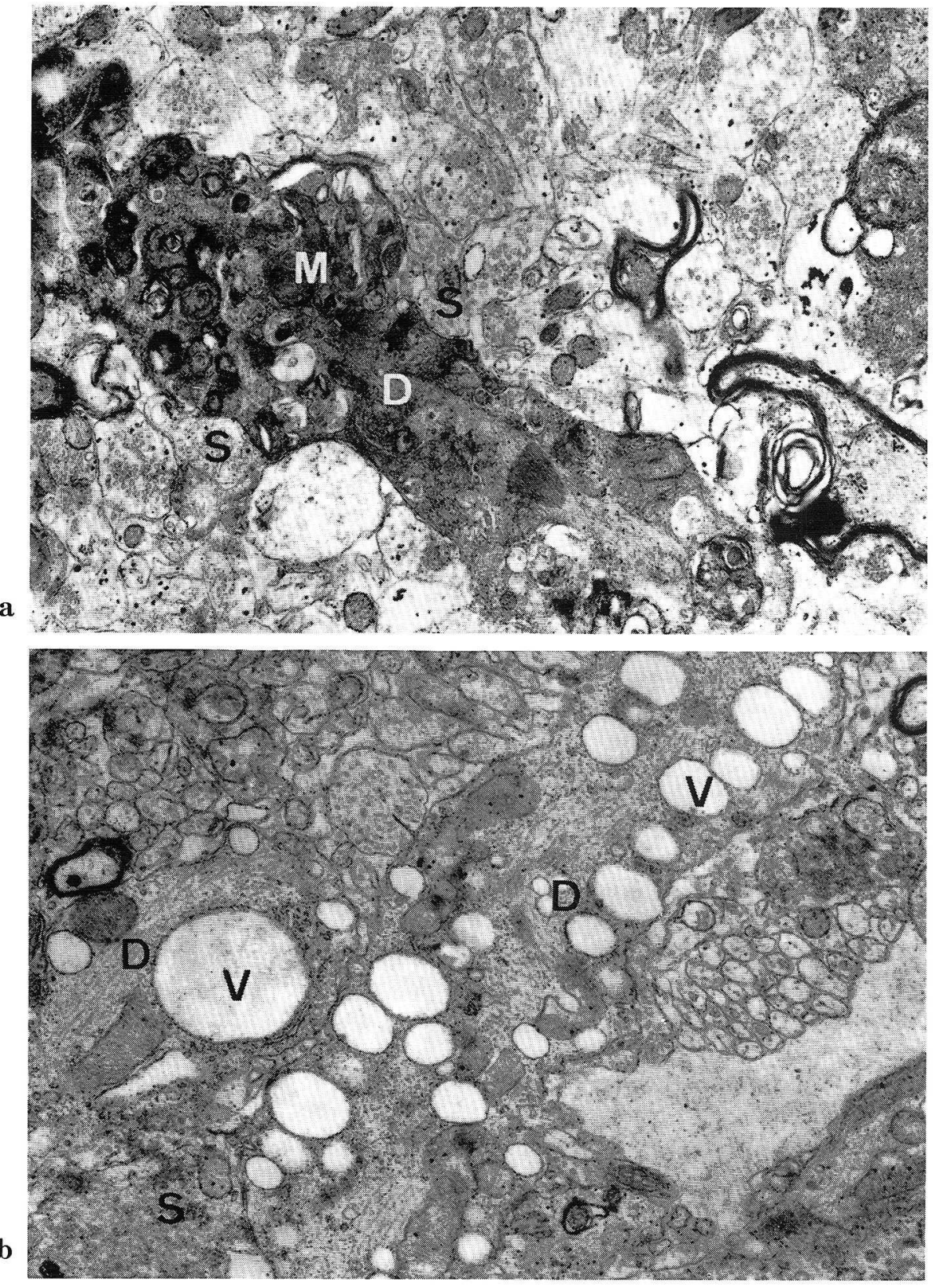

Fig. 3. $\mathbf{a}$ and $\mathbf{b}$. Electron micrographs showing degenerating dendrites in the stratum radiatum of the area $\mathrm{CA} 3$ of the hippocampal formation. a. A dark degenerating dendrite $(D)$ containing dense matrices, filaments, and many myeline figures $(M)$ at $8 \mathrm{hr}$ after injection. Several synapses still have the appearance of axo-dendritic synapses $(S) . \times 16,800$. b. Swollen degenerating dendrite $(D)$ with a watery appearance at $8 \mathrm{hr}$ after injection. Several vacuoles $(V)$ and disorganized mitochondria are apparent. A synaptic ending $(S)$ on the degenerating dendrite is cleary visible. $\times 13,900$ 

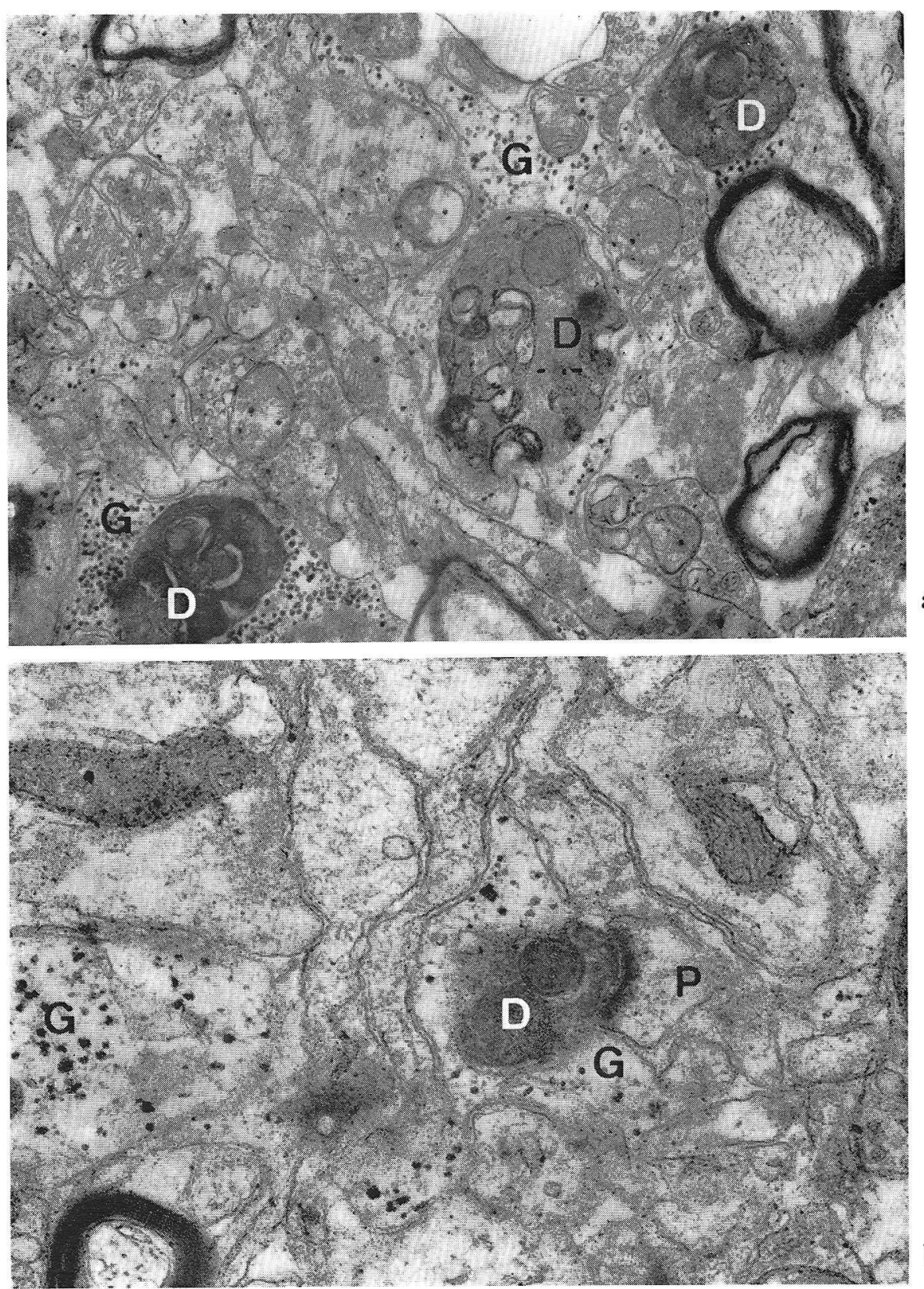

Fig. 4. a and b. Degenerating preterminal axons and terminals in the stratum radiatum of the area CA3 of the hippocampal formation. a. Note the dark profiles which are considered to be degenerating preterminal axons $(D)$ arising from dense matrices, myeline figures and dark mitochondria at $72 \mathrm{hr}$ after injection. The diameter of these dark profiles is almost the same as that of normal synapses. They are engulfed by glial processes $(G)$ containing glycogen particles. $\times 24,300$. b. A degenerating terminal $(D)$ which are seen at $72 \mathrm{hr}$ after injection. This ending still shows synaptic specialization of asymmetrical terminals and is surrounded by glial processes $(G)$ containing glycogen particles. $P$ postsynaptic dendrite. $\times 41,200$ 
number and only a few were scattered in the damaged area CA3 1 week after injection. At 3 weeks after injection it was almost impossible to find degenerating dendrites, but surviving or unaffected dendrites could still be observed.

Dark or swollen degenerating dendritic spines were hard to find and the number of normal dendritic spines, particularly in the mossy fiber endings, decreased progressively.

\section{Degeneration of myelinated axons}

Degenerating myelinatsd axons were first detected in area CA3 $8 \mathrm{hr}$ after injection. At this stage, however, they were not so prominent as degenerating perikarya and dendrites of the pyramidal cells. They contained electron dense matrices and numerous myeline figures. Some of them also showed degradation of their myeline sheath. They became most numerous $72 \mathrm{hr}$ after injection. At this stage many of them were also found in the fimbria hippocampi which is one of the main pathways of afferent and efferent fibers of the hippocampus. One week after injection they were still present in area CA3 despite the disappearance of degenerating neuronal perikarya and dendrites of the pyramidal cells.

\section{Degeneration of the preterminal axons and synaptic endings}

Degenerating preterminal axons first appeared in the stratum radiatum of area CA3 $72 \mathrm{hr}$ after injection. In light microscopic sections after FinK-HeImer's impregnation method I for degenerating preterminal axons and terminals we found large numbers of brown dots corresponding to degenerating preterminal axons and terminals in the stratum radiatum, stratum pyramidale and stratum oriens. Electron microscopically, they appeared as dense profiles containing various myelin figures and dense bodies. Some of them also contained dark vesicles. They also were frequently engulfed by glial processes (Fig. 4a). Degenerating synaptic endings with synaptic membrane specialization were also found (Fig. 4b). Their number gradually increased with the days following the injection. Some were still found 3 weeks after injection.

\section{Alterations in mossy fiber endings}

Characteristic morphological changes occurred in the mossy fiber endings $3 \mathrm{hr}$ after injection. They seemed to be floating in the extensively damaged neuronal elements of the pyramidal cells. In such preterminal boutons of the mossy fibers an accumulation of synaptic vesicles was apparent at various locations (Fig. 5a). However, they showed normal electron density and the mitochondria did also normal feature. The dendritic spines of the pyramidal cells seemed to decrease in number in such preterminal boutons. It became difficult to identify postsynaptic elements such as apical dendrites and their dendritic spines to the mossy fiber endings, but we occasionally observed clear synaptic formation between surving or degenerating dendrites and mossy fiber endings. Throughout this experimental stage we were able to demonstrate intimate contacts between the mossy fiber endings. Although they appeared less frequently they showed a synaptic-like specialization, and at certain sites synaptic vesicles were accumulated near the membrane thickening (Fig. 5b). In such mossy fiber endings only a few dendritic spines were observed. 

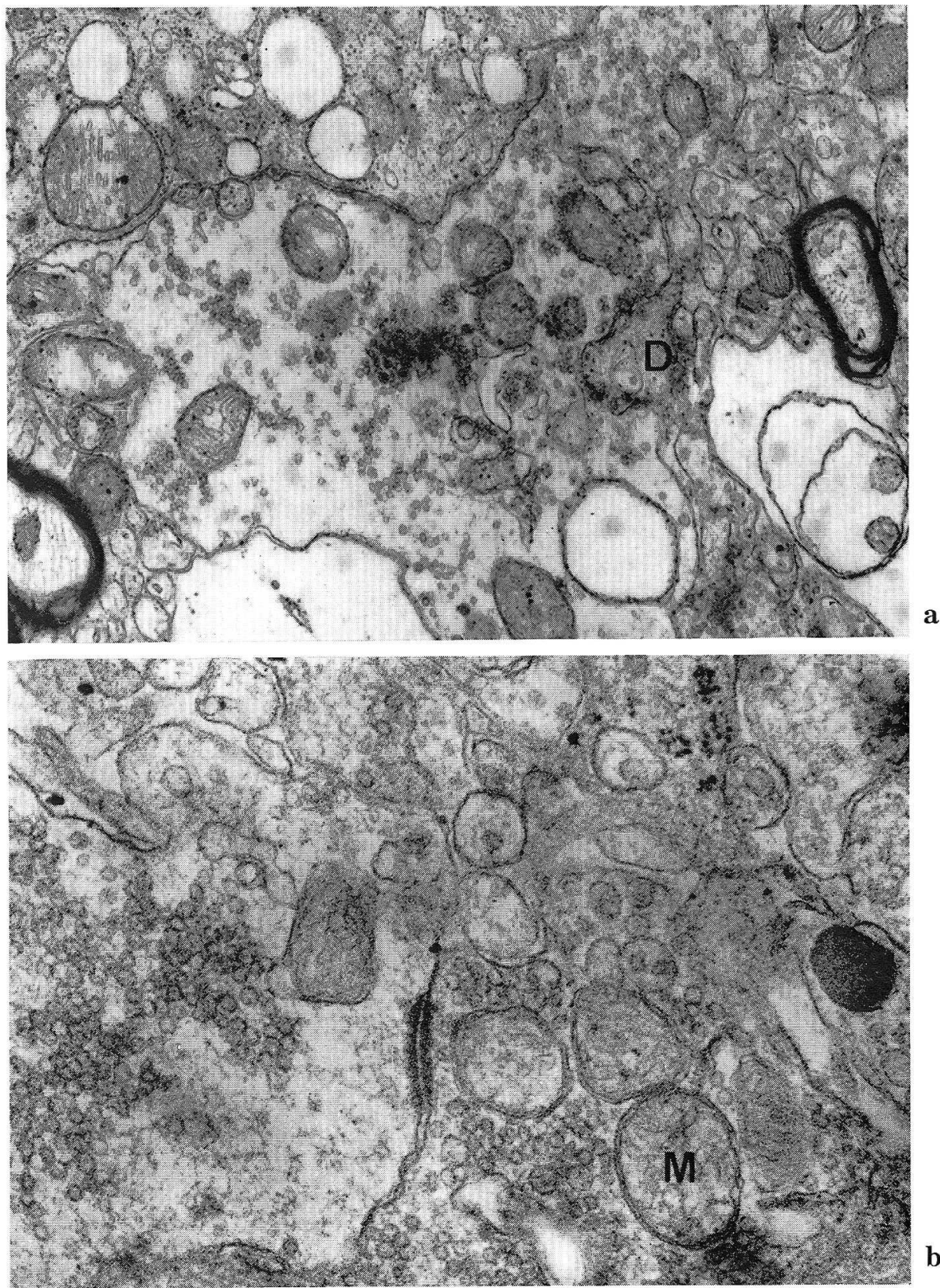

Fig. 5. a and b. Electron micrographs showing characteristic morphological changes in the mossy fiber endings in the stratum radiatum of the ares CA3 of the hippocampal formation. a. Accumulation of synaptic vesicles occurs at various places in the mossy fiber ending at $3 \mathrm{hr}$ after injection. A few dendritic spines $(D)$ are also present in this ending. $\times 21,500$. b. Intimate contact between mossy fiber endings is observed in this picture each of which contains synaptic vesicles and mitochondria $(M)$ at $24 \mathrm{hr}$ after injection. Symmetrical membrane thickening is observed on both sides. A few dendritic spines are also present in these endings. $\times 51,000$ 

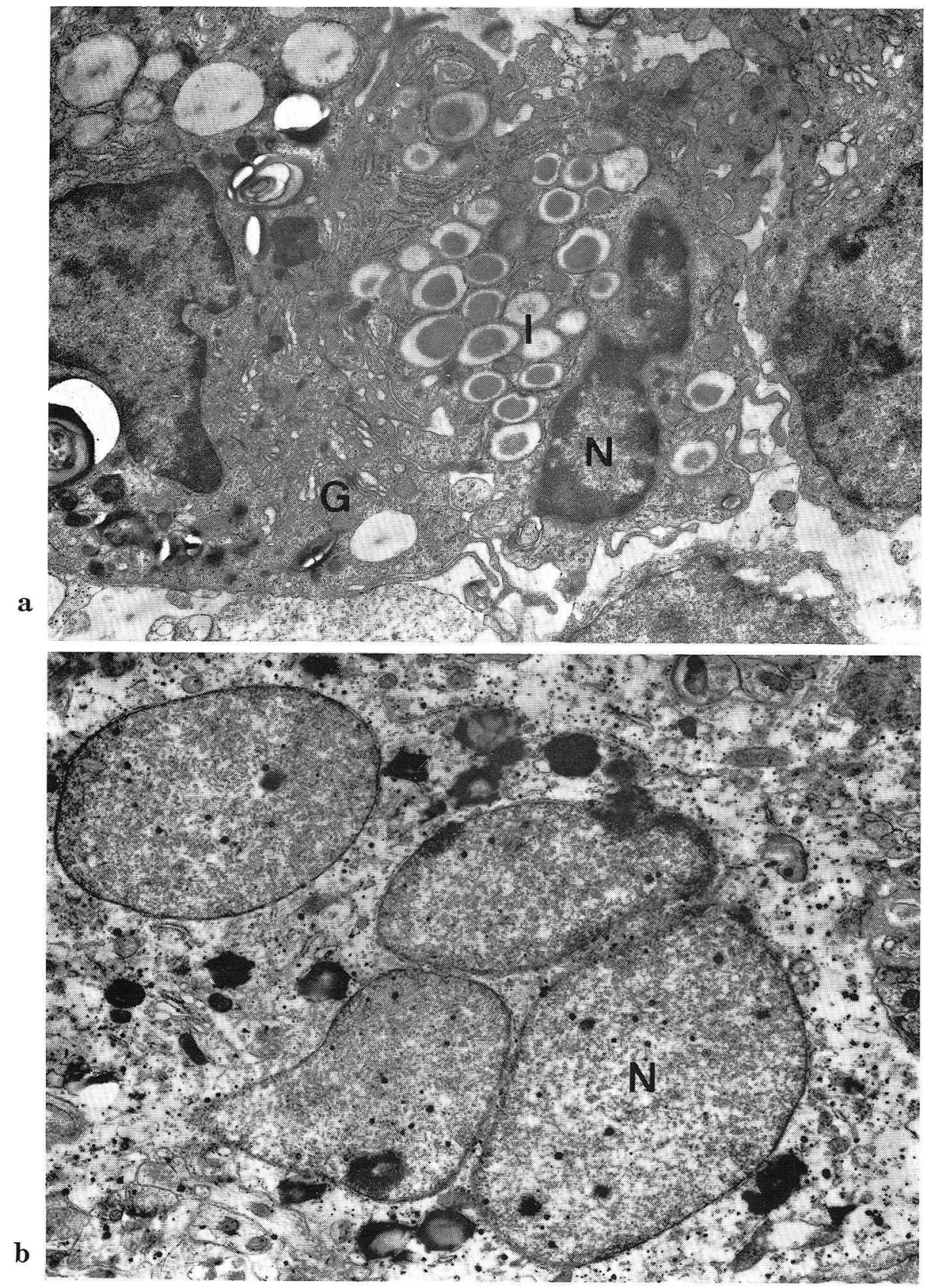

Fig. 6. a and b. Electron micrographs showing the feature of glial response in the damaged area of the area CA3 of the hippocampal formation. a. A macrophage containing electron dense matrices and several inclusions $(I)$ of fat-like droplets is observed in this picture at $72 \mathrm{hr}$ after injection. Cell organelles such as rough surfaced ER and Golgi complexes $(G)$ are also well developed in the perikaryon and microvilli-like protrusions are also observed on cell surface. $N$ nucleus. $\times 11,400$, b. A multinuclear astroglia containing dark inclusions is shown in this picture at 1 week after injection. Cell organelles such as ER and Golgi complexes are relatively well developed. $N$ nucleus. $\times 11,400$ 


\section{Glial responses after $\mathrm{KA}$ injection}

Within $24 \mathrm{hr}$ after injection the astroglia showed their most characteristic response in the damaged area CA3. They increased slightly in number and their processes contained many filaments, lysosomes and glycogen particles. Several macrophages containing numerous large inclusions of fat-like droplets and microvilli were observed $72 \mathrm{hr}$ after injection, and some of them also contained myelin figures (Fig. 6a). At this stage the glial cells, which seemed to be microglia because of the dark nuclei occupying the major part of the cell bodies, and their electron dense perikarya, also gradually increased in number. Approximately 1 week after injection a large number of microglia and their dark processes were observed particularly in the stratum oriens of area CA3, but macrophages were difficult to detect. Multinuclear astroglial cells with a moderate complement of cell organelles and dark inclusions were occasionally seen (Fig. 6b). After 3 weeks the glial cell population was similar to that at 1 week. In this stage, those glial cells with multinuclei and relatively well developed cell organelles were predominant. Microglia was also found in the damaged area, occupying wide spaces left by the deterioration of pyramidal neurons. Oligodendrocytes, however, showed little response throughout the experiment in comparison to other kinds of glia.

\section{DISCUSSION}

Degeneration of the restricted area CA3 of the dorsal hippocampal formation can be induced by small doses of KA injected into the lateral ventricles as described by NADLER et al. (1978). The pyramidal neurons and their dendrites are primarily influenced by the neurotoxicity of KA. We found four types of degenerating pyramidal cells in this experiment. The degenerating neurons with depleted cell organelles, and nuclei with poor chromatin development were considered to have a strong affinity for KA intoxication. These were completely damaged in the early stages. The second type of neuron, which contained several large vacuoles, may be a transitional form in the development to the above type since large vacuoles are believed to fuse together prior to degradation. Nearly all of these two types of degenerating pyramidal cells were observed at an early stage and it is probable that they show autolysis rather than signs of phagocytic action of glia, since we found large empty spaces at various parts in the damaged area prior to an increase of glial cells of macrophages. The third and fourth types of degenerating neurons we believe to be the remains of pyramidal cells with less susceptibility to neurotoxicity of KA, the former having shrunken and electron dense perikarya; the latter showing degradation of cell organelles and pyknotic changes in their nuclei. These types of degenerating neurons may be disposed of by glial phagocytosis. It is thought that the degree of degeneration of the neurons and dendrites is dependent on the capacity of glutamate receptor on the cell surface (OlNEY et al., 1979).

Degeneration of the dendrites appeared at almost the same time as the degeneration of the perikarya of the pyramidal neurons. Swollen and dark shrunken dendrites with vacuoles were distinguished. Some of them still remained as postsynaptic elements for mossy fiber endings of other preterminal axons. The swollen 
clear dendrites were particularly notable $8 \mathrm{hr}$ after injection. We consider them therefore to belong to the vacant degenerating neuronal soma. On the other hand, the degenerating dendrites with electron dense matrices are thought to belong to the degenerating pyramidal cells with shrunken configuration and high electron density. We were unable to detect massively swollen dendritic spines as postsynaptic elements of mossy fibers after peripheral administration of KA as reported by OLNEY et al. (1979). In the advanced stages of the experiment degenerating dendrites showing postsynaptic characteristics were hard to find since glial elements, such as astroglia or macrophages, displayed phagocytic response towards the dendritic processes. Dendritic spines invaginating into the mossy fiber endings wsre also decreased in number. The mechanism of the toxic effect on neuronal soma and dendrites remains unclarified, although some hypotheses have been presented. OLnEY et al. (1974) state that KA acts directly on the glutamate receptor sites of the neuronal soma and dendrites, whereas McGeER et al. (1978) consider that KA acts primarily on the glutaminergic nerve endings and the glutamate or KA metabolite secondarily released from them has a toxic effect on the glutamate receptors of postsynaptic dendrites and neuronal soma.

The appearance of degenerating myelinated axons was a consequence of degeneration in pyramidal neurons. Several degenerating axons originating from degenerating pyramidal cells in area CA3 were also found in the fimbria hippocampi. Therefore numerous degenerating nerve endings could be expected to appear in time in regions such as the septal area and the cingular gyrus where efferent projections from area CA3, passing through the dorsal fornix, have been identified (RAISMAN et al., 1966; SwANSON and Cowan, 1977). We were able in preliminary investigations to find several brown dots equating to degenerating terminals in the above regions $72 \mathrm{hr}$ after KA injection by FINK-HEIMER impregntion.

In the present study we found degenerating preterminal axons and endings in the damaged area. It has been generally accepted that preterminal axons or axons passing through are spared by KA injection (NADLER et al., 1978; Coyle, 1978; Olney, 1978), but the effects using neurochemical or histochemical techniques have suggested a possible vulnerability of preterminal axons or terminals (CoOPER et al., 1977; Meibach et al., 1978). More recently Mason and Fibiger (1979) suggested that significant damage to axons of passage may occur by the influence of KA on the axons of the dorsal noradrenergic bundle. There has been no report clearly indicating degenerating afferent fibers, other than nerve endings of intrinsic interneuron, by electron microscopy. Degenerating preterminal axons and terminals were clearly identified in this study. They appeared later than the degeneration of pyramidal neurons. We have no evidence that the degenerating terminals found in these experiments arise from outside of the hippocampus and we cannot rule out the possibility that some parts of the degenerating terminals are attridutable to intrinsic basket cells, probably GABAnergic, which terminate on the pyramidal cell soma as inhibitory synapses (ANDersen et al., 1963; Storm-Mathisen 1970). However in view of their proportions and site of termination including the information of FinKHEIMER's impregnation, we consider that relatively large numbers of them belong to nerve terminals arising from outside of the hippocampus. If the nerve endings arising from outside have degenerated, it may be interesting and significant to infer the mechanism of their degeneration in relation to their origin. Afferent fibers 
terminating in area $\mathrm{CA} 3$ have been verified by several procedures to be as follows: mossy fiber endings from the fascia dentata, cholinergic fibers from the septal area (Shute and Lewis, 1966; Storm-Mathisen, 1970; Wieraszko et al., 1977), monoamine fibers from the midbrain (SEgel and LANdis, 1974; PASQUier and Reinoso-Suarez, 1977; Kinoshita et al., 1977), fibers from the controlateral hippocampus via the commissure hippocampi (HJORTH-SiMONSEN, 1977) and fibers from ipsilateral subicular and entorhinal areas (Sw ANSON and Cow AN, 1977). We found no degenerating neuronal soma in the above regions in light microscopic sections stained with hematoxylineosin or Fink-Heimer's impregnation. Therefore a portion, at least, of the degenerating preterminal axons and terminals in the affected area might be ascribed not to Wallerian degeneration but to the toxic effects of KA on the terminal structures. Although further precise investigations are necessary to review the features and origin of degenerating terminals, we would emphasize that we found degenerating preterminal axons and terminals in area CA3 of the dorsal hippocampus after intraventricular injection of $\mathrm{KA}$, and suggested that they belong not only to the intrinsic neurons but to the neurons outside of the hippocampus.

In the mossy fiber endings we found an accumulation of synaptic vesicles randomly distributed. The number of whole synaptic vesicles they contained seemed to be less than those found in normal mossy fiber endings. This alteration of the mossy fiber endings might be due to their response to convulsive symptoms produced in the animals after KA injection. Another feature of note was the intimate contact between adjacent mossy fiber endings, some of which may be axo-axonal synapses. Several investigations into the fine structure of the mossy fiber endings have been carried out (Blackstad and KJaerheim, 1961; Hamlyn, 1962: Ibata, 1968), but no description of such an intimate adhesional contact has been made in normal hippocampal material of several mammalian species. We may suppose therefore that these structures are the consequence of deterioration of their postsynaptic elements such as pyramidal cell somata, dendrites and dendritic spines. It is by no means certain, however, that synaptic transmission ever takes place between them.

Throughout this experiment the response of the glia to the damage in area CA3 was an increase in the number of astroglia and macrophages from an early stage and they presumably may play a role of scavenger of degenerating pyramidal cells and their dendrites. In the later stages, i.e., approximately 3 weeks after injection the microglia as well as the astroglia also increased in number and were mobilized for scar formation in the damaged area by occupying the empty spaces left after deterioration of pyramidal neurons. The response and role of the neuroglia after $\mathrm{KA}$ injection will be reported elsewhere.

\section{カイニン酸のラット海馬 CA3 野に対する影響について—電子顕微鏡的研究}

小幡裕子，久保清一，木下晴生，村部義則，井端泰彦

少量のカイニン酸をラットの側脳室に投与し，海馬 CA3 野に対する影響について、投与 1 時間後より 3 週後まで，経時的に電顕により観察を行なった。投与後， 3 洔間くらいよ り，激しい変性が錐体細胞の細胞体や樹状突起に認められた．錐体細胞の変性は，大きく 
4種類に分けられ，おそらくカイニン酸に対する感受性を反映していると考えられる. また，今回の実験で，錐体細胞の变性に加えて，軸索の終末や 終末前軸索に 变性が認め られた。歯状回からの突起である苔状線維の終末には，初期において 形態上，変化をみと め，また，苔状線維終末どうしのシナプスと考えられる構造も認められた。CA3野の变性 に応じて，グリアの反応も激しく，初期においては星状膠細胞や大食細胞が増加し，変性 後の組織には 小膠細胞や星状膠細胞が動員されていた。

\section{REFERENCES}

Andersen, P., J. C. Eccles and Y. Løyning: Hippocampus of the brain. Recurrent inhibition in the hippocampus with identification of the inhibitory cell and its synapses. Nature 196: $540-542$ (1963).

Blackstad, T. W. and A. Kjaerheim : Special axo-dendritic synapses in the hippocampal cortex. Electron and light microscopic studies on the layer of mossy fibers. J. comp. Neurol. 117: 133-149 (1961).

Cooper, B. R., R. M. Ferris and H. L. White: Behavioral, biochemical and morphological changes after intrastriatal injections of kainic acid (KA). Neurosci. Abstr. 3: 439 (1977).

Coyle, J. T.: Neuronal mapping with kainic acid. Trends Neurosci. 1: 132-135 (1978).

Hamlyn, L. H.: The fine structure of the mossy fiber endings in the hippocampus of the rabbit. J. Anat. (Lond.) 96: 112-119 (1962).

Hattori, T. and E. G. McGeer : Fine structural changes in the rat striatum after local injections of kainic acid. Brain Res. 129: 174-180 (1977).

Heimer, L.: Selective silver-impregnation of degenerating axoplasm. In: (ed. by) W. J. H. Nauta and S. O. E. Ebbesson: Contemporary research methods in neuroanatomy. Springer-Verlag, New York-Heidelberg-Berlin, 1970 (p. 106-131).

Herndon, R. M. and J. T. Coyle: Glutaminergic innervation, kainic acid, and selective vulnerability in the cerebellum. In: (ed. by) E. G. McGeer, J. W. Olney and P. L. McGeer: Kainic acid as a tool in neurobiology. Raven Press, New York, 1978 (p. 189-200).

Hjorth-Simonsen, A.: Distribution of commissural afferents to the hippocampus of the rabbit. J. comp. Neurol. 176: 495-513 (1977).

Ibata, Y.: Electron microscopy of the hippocampal formation of the rabbit. J. Hirnforsch. 10: 451-469 (1968).

Kinoshita, H., H. Kimura and Y. Ibata : Distribution of catecholamine nerve terminals in the hippocampal formation of the rat and the cat. In: XVIII International Congress of Neurovegetative Research Proceedings. Tokyo, 1977 (p. 328-330).

Mason, S. T. and H. C. Fibiger : On the specificity of kainic acid. Science 204: 1339-1341 (1979).

McGeer, E. G., J. W. Olney and P. L. McGeer : Kainic acid as a tool in neurobiology. Raven Press, New York, 1978.

Meibach, R. C., L. Brown and F. H. Brooks : Histofluorescence of kainic acid-induced striatal lesions. Brain Res. 148: 219-223 (1978).

Mizukawa, K., K. Shimizu, T. Matsuura, Y. Ibata and Y. Sano: The influence of kainic acid on the tuberoinfundibular dopaminergic tract of the rat: Fluorescence histochemistry and electron microscopic investigation. Acta histochem. cytochem. 9: 315-322 (1976).

Nadler, J.V., B. W. Perry and C. W. Cotman: Intraventricular kainic acid preferentially destroys hippocampal pyramidal cells. Nature 271: 676-677 (1978).

Olney, J. W.: Neurotoxicity of excitatory amino acids. In: (ed. by) E. G. McGeer, J. W. Olney and P. L. McGeer: Kainic acid as a tool in neurobiology. Raven Press, New York, 1978 (p. 95-123). 
Olney, J. W., T. Fuller and T. De Gubareff : Acute dendrotoxic changes in the hippocampus of kainate treated rats. Brain Res. 176: 91-100 (1979).

Olney, J. W., V. Rhee and O. I. Ho: Kainic acid: a powerful neurotoxic analogue of glutamate. Brain Res. 77: 507-512 (1974).

Pasquier, D. A. and F. Reinoso-Suarez: Differential efferent connections of the brain stem to the hippocampus in the cat. Brain Res. 120: 540-548 (1977).

Raisman, G., W. M. Cowan and T. P. S. Powell: An experimental analysis of the efferent projection of the hippocampus. Brain 89: 83-108 (1966).

Segal, M. and S. Landis: Afferents to the hippocampus of the rat studied with the method of retrograde transport of horseradish peroxidase. Brain Res. 78: 1-15 (1974).

Seil, F. J., N. K. Blank and A. L. Leiman : Toxic effects of kainic acid on mouse cerebellum in tissue culture. Brain Res. 161: 253-265 (1979).

Seil, F. J., W. R. Woodward, J. K. Blank and A. L. Leiman : Evidence against chronic depolarization as a mechanism of kainic acid toxicity in mouse cerebellar cultures. Brain Res. 159: 431-435 (1978).

Shute, C. C. D. and P. R. Lewis : Electron microscopy of cholinergic terminals and acetylcholinesterase-containing neurones in the hippocampal formation of the rat. Z. Zellforsch. 69: 334343 (1966).

Storm-Mathisen, J.: Quantitative histochemistry of acetyl cholinesterase in rat hippocampal region correlated to histochemical staining. J. Neurochem. 17: 739-750 (1970).

Swanson, L. W. and W. M. Cowan : An autoradiographic study of the organization of the efferent connections of the hippocampal formation in the rat. J. comp. Neurol. 172: 49-84 (1977).

Wieraszko, A., B. Oderfeld-Nowak and O. Narkiewicz: Ipsi- and contralateral changes in acethylcholinesterase and choline acethyltransferase activities in the hippocampus following unilateral lesions in the rat. Neuroscience 2: 649-654 (1977).

Wuerthele, S. M., K. L. Lovell, M. Z. Jones and K. E. Moore: A histological study of kainic acid induced lesions in the rat brain. Brain Res. 149: 489-497 (1978).

\author{
井端泰彦 \\ 厂602 京都市上京区河原町広小路 \\ 京都府立医科大学 \\ 第二解剖学教室
}

Prof. Yasuhiko IвATA

Department of Anatomy

Kyoto Prefectural University of Medicine

Kawaramachi-Hirokoji, Kyoto

602 Japan 